\title{
Daily use of phosphodiesterase type 5 inhibitors as prevention for recurrent priapism
}

\author{
Archimedes Nardozza Junior ${ }^{1 *}$, Marcelo Rodrigues Cabrin $2^{2}$ \\ ${ }^{1}$ Associate Professor of Urology, Escola Paulista de Medicina, Universidade Federal de São Paulo (Unifesp), São Paulo, SP, Brazil \\ ${ }^{2} \mathrm{PhD}$ in Medicine and Assistant Professor of Urology, Escola Paulista de Medicina, Unifesp, São Paulo, SP, Brazil
}

Study conducted at Escola Paulista de Medicina, Universidade Federal de São Paulo, São Paulo, SP, Brazil

Article received: $7 / 3 / 2017$ Accepted for publication: $7 / 21 / 2017$ *Correspondence: Address: Rua Tabapuã, 50, cj. 201 São Paulo, SP - Brazil Postal code: 05611-050 anardozza@globo.com

http://dx.doi.org/10.1590/1806-9282.63.08.689

\section{SUMMARY}

Objective: The pathogenesis of recurrent priapism is currently being investigated based on the regulation of the phosphodiesterase 5 (PDE5) enzyme. We explored the daily use of PDE5 inhibitors to treat and prevent priapism recurrences.

Method: We administered PDE5 inhibitors using a long-term therapeutic regimen in seven men with recurrent priapism, with a mean age of 29.2 years (range 21 to 35 years). Six men (85.7\%) had idiopathic priapism recurrences and one man (24.3\%) had sickle cell disease-associated priapism recurrences. Tadalafil $5 \mathrm{mg}$ was administered daily. The mean follow-up was 6.6 months (range 3 to 12 months) Results: Daily long-term oral PDE5 inhibitor therapy alleviated priapism recurrences in all patients. Five (71.4\%) had no episodes of priapism and two $(28.6 \%)$ referred decrease in their episodes of priapism. All patients referred improvement in erectile function.

Conclusion: These findings suggest the hypothesis that PDE5 dysregulation exerts a pathogenic role for both sickle cell disease-associated priapism and for idiopathic priapism, and that it offers a molecular target for the therapeutic management of priapism. These preliminary observations suggest that continuous long-term oral PDE5 inhibitor therapy may treat and prevent recurrent priapism.

Keywords: priapism, cyclic nucleotide phosphodiesterases type 5, erectile dysfunction.

\section{INTRODUCTION}

Priapism is a persistent penile erection that continues for hours and is unrelated to sexual stimulation. The corpora cavernosa are the structures affected although tumescence of the corpus spongiosum has also been observed. ${ }^{1}$

It is commonly perceived to be an infrequently occurring medical disorder, and most recognizably afflicts men with sickle cell disease (SCD), in whom the prevalence rate of priapism exceeds $40 \%$ and the rate of erectile dysfunction as a sequela from priapism approximates $30 \%{ }^{2}$

Ischemic priapism, the most common subtype, is associated with acidic and hypoxemic cavernous blood as measured by a $\mathrm{pH}$ and $\mathrm{pO}_{2}$ less than the normal values found in mixed venous blood of 7.35 and $40 \mathrm{mmHg}$, respectively. It is typically accompanied by pain and is associated with ischemic effects within the penis equivalent to a compartment syndrome of an extremity.

The end-stage pathologic features consist of erectile tissue necrosis and genital organ fibrosis, which hinders normal erectile tissue hemodynamic responses, with a substantial risk of subsequent erectile dysfunction (ED). The initial management of choice is corporal aspiration with injection of sympathomimetic agents. If medical management fails, a cavernosal shunt procedure is indicated.

The natural history of priapism commonly involves recurrent short-lived episodes, which frequently forecast a subsequent major episode. ${ }^{3}$

Stuttering or recurrent ischemic priapism (RIP), a relatively rare condition, is a recurrent form of ischemic priapism in which unwanted painful erections occur repeatedly with intervening periods of detumescence. ${ }^{2}$

The exact mechanism of RIP is unknown and the clinical course of this disorder for many patients includes multiple emergency room visits and surgical shunt procedures. They may necessitate penile prosthesis implantation for irreversible corporal fibrosis and resultant ED.

However, significant advances in the study of erectile physiology during the 1980s and 1990s have led to a bet- 
ter understanding of priapism and many pathophysiological hypotheses, including medication-related blockade of vascular tone.

Many preventive systemic therapies have been described, including oral baclofen, digoxin, terbutaline, sympathomimetic drugs and gonadotropin-releasing hormone $(\mathrm{GnRH})$ agonists or antiandrogens. ${ }^{4}$

Current basic science progress in the field suggests that priapism in various instances may result from disturbances in the regulatory control of the main molecular pathway mediating penile erection, the nitric oxide-signaling pathway.

This deregulation specifically involves the reduced expression of phosphodiesterase-5 (PDE5) in the penis.

Based on this theory, we proposed the use of PDE5 inhibitors as a preventative strategy for the disorder.

\section{Method}

We evaluated prospectively seven men with mean age of 29.2 years (range from 21 to 35 years) who had presented to our local hospital emergency room or our erectile dysfunction outpatient clinic with repeated episodes of persistent penile erection in the absence of sexual interest or desire.

Six of them (85.7\%) had idiopathic priapism recurrences and one $(24.3 \%)$ had sickle cell disease-associated priapism recurrences.

For each patient, standard history and physical examinations were performed. Clinical histories particularly documented priapism characteristics (e.g., duration, frequency), role of antecedent factors, prior priapism episodes, use and success of relieving maneuvers (Table 1).

Patient 5 was the only one who could achieve spontaneous resolution of the episodes. Six of the patients were submitted to intervention, being that five needed aspiration only, and one (patient 4) needed Winter procedure. None of them had used any preventive therapy before.

They were informed about their risk of progression to developing major complications of priapism recurrence and the possibility of preventing new episodes according to the new theory of recurrent priapism.

The program consisted of using PDE5 inhibitors "off-label" as a long-term, continuous therapeutic regiment. Tadalafil was administered at a $5 \mathrm{mg}$ daily dose.

All patients were informed about the risks and contraindications of the drug.

They were able to reach the urologic staff at any time 24 hours a day in our local hospital. The plan of scheduled contacts included outpatient visits every 3 weeks for the first 6 months. The mean follow-up was 6.6 months (range 3 to 12 months).

\section{Results}

Results are displayed in Table 2. Patient 2 was the only one affected by SCD. Mean frequency of priapism was 3.14 episodes/week. The follow-up was 6.6 months. All patients tolerated the use of sildenafil with no adverse effects.

During the treatment, only two men had recurrent priapism episodes but with a reduction in frequency and duration (patients 4 and 6 ). Five patients (71.4\%) had zero episodes of priapism (Table 2).

Patients 1, 2, 3 and 7, who had the lowest frequency, and patient 5, who had spontaneous resolution of the episodes, have not reported any episodes since the beginning of the therapy. After termination of the follow-up program, only patients 4 and 6 had some recurrent priapic episodes, with spontaneous resolution. It is worth noting that patient 4 was the only one to undergo Winter procedure, while patient 6 was the one who had episodes for the longest time.

\section{Discussion}

The proposal of using PDE5 inhibitors to prevent RIP would immediately seem illogical based on the knowledge that this drug exerts erectogenic effects.

The implication is that deregulatory mechanisms provide a basis for priapism to occur as a manifestation of an unbalanced erectile tissue response.

\section{TABLE 1 Clinical history of the patients.}

\begin{tabular}{|c|c|c|c|c|c|c|c|}
\hline Patient & Age & Race & $1^{\text {st }}$ episode & Episodes/week & Duration & Etiology & Intervention \\
\hline 1 & 36 & White & 3 months & 1 & $12 \mathrm{~h}$ & idiopathic & aspiration \\
\hline 2 & 28 & White & 1 year & 1 & $4 \mathrm{~h}$ & SCD & aspiration \\
\hline 3 & 21 & White & 1 year & 1 & $3 \mathrm{~h}$ & idiopathic & aspiration \\
\hline 4 & 36 & White & 6 months & 7 & $4 \mathrm{~h}$ & idiopathic & aspiration + Winter \\
\hline 5 & 25 & Black & 6 months & 7 & $6 \mathrm{~h}$ & idiopathic & spontaneous \\
\hline 6 & 32 & White & 2 years & 3 & $6 \mathrm{~h}$ & idiopathic & aspiration \\
\hline 7 & 27 & White & 1 year & 2 & $4 \mathrm{~h}$ & idiopathic & aspiration \\
\hline
\end{tabular}

SCD: sickle cell disease. 


\section{TABLE 2 Study's results.}

\begin{tabular}{|c|c|c|c|c|c|}
\hline Patient & Age & Episodes/week & Intervention & Follow-up (month) & Episodes after PDE5 \\
\hline 1 & 36 & 1 & aspiration & 5 & 0 \\
\hline 2 & 28 & 1 & aspiration & 7 & 0 \\
\hline 3 & 21 & 1 & aspiration & 12 & 0 \\
\hline 4 & 36 & 7 & aspiration + Winter & 8 & 1 \\
\hline 5 & 25 & 7 & spontaneous & 3 & 0 \\
\hline 6 & 32 & 3 & aspiration & 5 & 2 \\
\hline 7 & 27 & 2 & aspiration & 6 & 0 \\
\hline
\end{tabular}

PDE5: phosphodiesterase type 5 .

Claudino et al. reported that, in mice, relaxation of the cavernosal smooth muscle occurs as a response to activation of the nitric oxide and cyclic GMP (NO-cGMP) signaling pathway. $\mathrm{NO}$ produced in nitrergic neurons and sinusoidal endothelium binds the soluble guanylyl cyclase (sGC), increasing the synthesis of cGMP, which leads to smooth muscle relaxation and hence penile erection. cGMP levels are regulated by the rate of synthesis and the rate of hydrolyzing mediated by phosphodiesterase type 5 (PDE5). ${ }^{5}$

Consistent with the physiologic function of cGMP to induce smooth muscle relaxation in the penis required for penile erection, excessive amounts of cyclic nucleotide account for the prolonged erectile tissue relaxation that manifests as priapism.

Champion et al. described the pathophysiology of stuttering priapism on a molecular level in studies using endothelial nitric oxide (eNO) synthase knockout mice, which phenotypically display priapism. They have shown a reduction in PDE5 expression which, when restored, corrects the priapism. ${ }^{6}$

The preventive strategy was based on previous reports on the feasibility of PDE5 for pharmacologic prevention of recurrent priapism in patients with SCD and hemoglobinopathies. ${ }^{7}$

Based on basic research studies, it has been suggested that PDE5 function in the penis may be up-regulated by long-term treatment with PDE5 inhibitor. ${ }^{8}$ Burnett and Bivalacqua ${ }^{9}$ reported on the therapeutic value of long-term use of PDE5 inhibitor. ${ }^{9}$

While recognizing the limitations of our study regarding the small population and the lack of a control group, the fact that RIP is a relative rare condition must be acknowledged. There are few prospective studies of preventive therapy and these outcomes can lead to other comparative trials.

\section{Conclusion}

Our findings suggest the hypothesis that PDE5 deregulation exerts a pathogenic role for both sickle cell disease- -associated priapism and for idiopathic priapism, and that it offers a molecular target for the therapeutic management of priapism.

These preliminary observations suggest that continuous long-term oral PDE5 inhibitor therapy may treat and prevent recurrent priapism. A large randomized study is still needed to confirm clinical effectiveness, although advantages have been shown for this revolutionary treatment alternative.

\section{Resumo}

Prevenção do priapismo recorrente com a utilização diária de inibidores da fosfodiesterase tipo 5

Objetivo: Uma das teorias propostas para explicar a etiologia do priapismo recorrente está baseada no mecanismo de regulação da fosfodiesterase tipo 5. Estudamos o uso diário dos inibidores de fosfodiesterase tipo 5 no tratamento e na prevenção do priapismo recorrente.

Método: Sete homens com diagnóstico de priapismo recorrente, com idade média de 29,5 anos (21 a 35 anos), utilizaram inibidor de fosfodiesterase tipo $5 \mathrm{em}$ dose diária (tadalafila $5 \mathrm{mg} /$ dia) por período prolongado. Seis homens $(85,7 \%)$ apresentavam priapismo recorrente de etiologia idiopática, e um homem (24,3\%), de etiologia associada à anemia falciforme. O seguimento médio foi de 6,6 meses ( 3 a 12 meses).

Resultados: Todos os pacientes se beneficiaram com a utilização de inibidores de fosfodiesterase tipo 5. Cinco $(71,4 \%)$ não apresentaram nenhum episódio de priapismo e dois $(28,6 \%)$ relataram diminuição dos episódios. Todos os pacientes relataram melhora da função erétil.

Conclusão: Estes achados sugerem que a hipótese do mecanismo de regulação da fosfodiesterase tipo 5 exerce papel importante na patogenia do priapismo recorrente. O uso contínuo e diário de inibidores da fosfodiesterase tipo 5 pode ser uma opção no tratamento do priapismo recorrente. 
Palavras-chave: priapismo, fosfodiesterases nucleotídicas cíclicas tipo 5, disfunção erétil.

\section{References}

1. Burnett AL, Bivalacqua TJ. Priapism: current principles and practice. Urol Clin North Am. 2007; 34(4):631-42.

2. Burnett AL, Bivalacqua TJ, Champion HC, Musicki B. Long-term oral phosphodiesterase 5 inhibitor therapy alleviates recurrent priapism. Urology. 2006; 67(5):1043-8.

3. Montague DK, Jarow J, Broderick GA, Dmochowski RR, Heaton JP, Lue TF, et al.; Members of the Erectile Dysfunction Guideline Update Panel; American Urological Association. American Urological Association guideline on the management of priapism. J Urol. 2003; 170(4 Pt 1):1318-24.
4. Abern MR, Levine LA. Ketoconazole and prednisone to prevent recurrent ischemic priapism. J Urol. 2009; 182(4):1401-6.

5. Claudino MA, Franco-Penteado CF, Corat MA, Gimenes AP, Passos LA, Antunes E, et al. Increased cavernosal relaxations in sickle cell mice priapism are associated with alterations in NO-cGMP signaling pathway. J Sex Med. 2009; 6(8):2187-96.

6. Champion HC, Bivalacqua TJ, Takimoto E, Kass DA, Burnett AL. Phosphodiesterase-5A dysregulation in penile erectile tissue is a mechanism of priapism. Proc Natl Acad Sci U S A. 2005; 102(5):1661-6.

7. Burnett AL, Bivalacqua TJ, Champion HC, Musicki B. Feasibility of the use of phosphodiesterase type 5 inhibitors in a pharmacologic prevention program for recurrent priapism. J Sex Med. 2006; 3(6):1077-84.

8. Lue TF, Hellstrom WJ, McAninch JW, Tanagho EA. Priapism: a refined approach to diagnosis and treatment. J Urol. 1986; 136(1):104-8.

9. Burnett AL, Bivalacqua TJ. Glucose-6-phosphate dehydrogenase deficiency: an etiology for idiopathic priapism? J Sex Med. 2008; 5(1):237-40. 